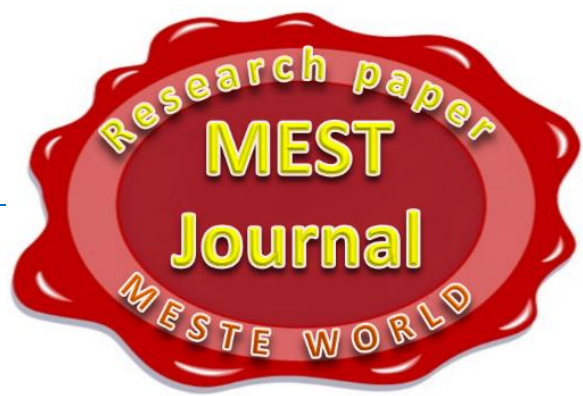

\title{
FINANCIAL MANAGEMENT OF MONETARY FLOWS IN UKRAINE
}

\author{
Iurii Vasyliovych Pasichnyk \\ Department of Finance, Cherkasy State Technological University, Cherkasy, Ukraine
}

\section{(C) MESTE NGO}

JEL category: E52, E63, H6

\begin{abstract}
The essence and specific features of cash flows of the Consolidated Budget of Ukraine, income and spending, the banking sector are studied. Theoretical trends explaining the origin and formation of the cash flows are analyzed. The classification of cash flows according to six basic features - type, direction, nature of the impact, hierarchical levels, levels of control, elements of the financial system has been developed. The comparison of some countries of the world with Ukraine on the indicators of territory, population, unemployment, the average monthly wage, GDP and exchange rates is presented. The structure of GDP by income in 2012 was analyzed. Therefore in the result of the stated analysis it has been discovered that the wages (51\%), gross profit and mixed income $(34.8 \%)$ constitute the greater proportion.

The reasons hindering the effective administration of the tax to the state budget are studied. To ensure effective tax administration and the formation of optimal flows of the Consolidated budget of Ukraine relevant principles are offered. The financial flows of the population, in particular the income and expenditure structure in 2012, are analyzed in details. The analysis revealed that the greater part of the income structure belongs to wages (42.2\%), and the cost structure includes the purchase of goods and services (83.8\%). 2009-2012 The available supply of money in circulation and deposits of households for the period of 2009-2012 was analyzed. The appropriateness of management of these funds for advanced manufacturing and innovation has been studied. The appropriate methods of forecasting of cash flows of mathematics are offered. Reasonable suggestions for effective management of financial flows in Ukraine in the fields of corruption reducing, tax legislation improving, and the formation of effective control mechanisms are grounded.
\end{abstract}

Keywords: incomes and spendings, consolidated budget, financial flows, financial management.

\section{ESSENCE AND PARTICULARIZES OF FINANCIAL FLOWS.}

In today's world economic reality processes financial flows take an increasing importance. The

Address of the author: lurii Vasyliovych Pasichnyk 麦=" pasich_fin@mail.ru consequences of the global financial crisis showed that the loss of control of a virtual financial capital leads to a contradiction between the world's financial centers, groups of countries, forms the so-called "swelling" (over-accumulation) of the unsecured "financial bubbles", or so-called virtual finance, when the speed of financial transactions exceeds commodity ones. 
As noted by V. Bourtsev in modern terms financial factors of world economic system transformation take an enormous importance:

- a rapid development of trans-nationalization process of economic relations, the integration of national financial markets, globalization of the world economy;

- permanent weakening of the regulation of the world financial markets;

- expansion of the global financial system by means of incorporation into the world economy of the developing countries;

- steady increase in the great mass of capital, high concentration of capital on both macroand micro- levels of a state;

- the tendency towards capital concentration, increasing autonomy of major financial players who have a significant financial power;

- a significant number of financial instruments and a high level of their dynamism;

- competition and conflict increase among states in economic and other fields, the use of aggressive strategies by powerful market participants, capture of the world economic area (Burtsev, 2001, p. 23).

World economic system of XXI century is fundamentally new than it was in the XVI-XVII centuries, when independent financial resources were formed, functioning as the corresponding flows.

As E. Lazicheva (2009) notes the finance importance means that the way to regulate the distribution relationship may affect the economic output, economic growth and thereby control the economic and social development of any territory. In today's realities, in particular in the literature on financial management, there hardly can be distinction between financial and cash flow in understanding of the nature of financial flows [ (Senchagov \& Arkhipov, 2007), (Romanovski, 2009), (Tikhomirov, 2008)].

In the modern sense, the financial flow consists of identical as follows from its content elements that are the essence of money. Therefore, cash flows can deterministically be regulated by the state, corporate bodies and the population. Destabilization of financial flows is possible due to the loss of control on the part of the corresponding subjects.
Over the past four centuries when financial flows became so great that were reflected in the relevant economic directions, in particular, including cameralism, one of the first developed. Their evolution varied around the basic postulate, the level of state intervention in economic processes. Proponents of one approach, starting from Adam Smith, included monetarism, the theory of a free market by F. Hayek, and many other schools, proved the effectiveness of self-regulation of business processes of market mechanisms.

Supporters of the other one, the Keynesians and their numerous followers, considered the effectiveness of financial flows to be in a strict government regulation.

With varying degrees of success these approaches have been used over four centuries, however XXI century is characterized by a fundamentally new quality and volumes of financial flows. Globalization has led to another characteristic that is the absence of control by the intergovernmental financial institutions, governments and some corporations. U.S. President Barack Obama once said that it is necessary to forget the myth of the "invisible hand of the market". He pronounced this speech at the end of the first decade of XXI century, when the United States was covered by a wave of financial turmoil. Also the following years, during which the governments of almost all countries tried to boost the economy in a centralized manner, confirmed the lack of effectiveness of market regulation.

It is appropriate to recall the prophetic words of J.K. Galbraith that in the future all the benefits of capitalism (the prevailing market economy) and socialism (the prevailing state regulation) will be used.

Let us consider some views on the theoretical study of financial flows management.

According to the present day synergetic approaches to the evolution of the world economic development, including the role of financial flows one should take into consideration the fact that the world is dual and that is its main characteristic; it is enough to mention the main elements of its structure, confirming it - day and night, man and woman, black and white, positive and negative, etc.

The synergetic approach means that the flows that must be controlled by the state, and lower order flows must be monitored by the relevant economic 
participants. This combination can be effective. If the basic functions of the financial system are broken, the distribution and control ones, there appears corruption, abuse, inefficient use of resources, etc. that reduces the level of GDP, lowers economic growth. The reduction of living standards is the result of these processes.
The lower cash flow accountability at all levels of the economy, the greater the likelihood of embezzlement of budget funds, in some cases leading to the social disruption.

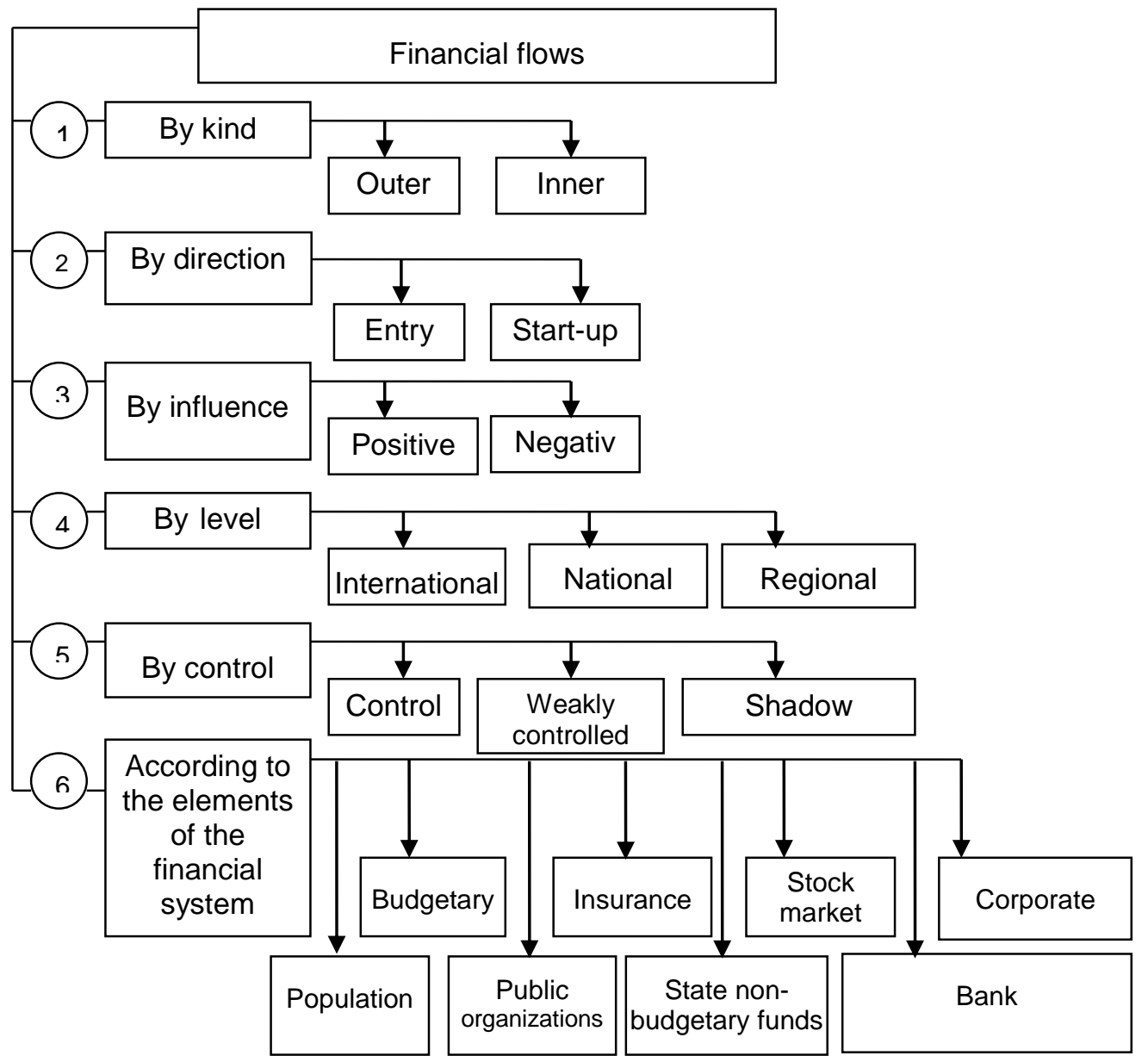

Fig. 1. Classification of financial flows

As it can be seen from Fig. 1, there is a whole variety of financial flows. Their effective management needs creation and implementation of positive flows under the permanent control of public entities with independent experts, specialists in this area, analytical agencies. But the control is not enough; response mechanisms must be formed as a part of the state, corporations and public agencies. That's the way to ensured social progress.

V.O. Kyo expressed an appropriate idea about this situation: "The power owned by business in the American politics, will confuse an individual with democratic tendencies: a relatively insignificant minority has an extraordinary power" (Olson, 2004, p. 192).

Therefore, in today's reality monetary flows must be not only optimally and efficiently formed at all hierarchical levels, but also must establish their effective management and control of their occurrence with the appropriate response mechanisms.

To clarify the nature and significance of the place of Ukraine in the world economic system and identify the volume of financial flows in Ukraine let us study key indicators of the some countries, table 1 (Derzhavna sluzhba statystyky Ukrayiny, 2013, pp. 517-542). 
Pasichnyk I.V. Financial management of monetary flows in Ukraine

MEST Journal Vol. 3 No. 1 pp. 1-10

Table 1 Basic indices of some countries and Ukraine (data for 2011 year)

\begin{tabular}{|l|r|r|r|r|r|}
\hline \multirow{2}{*}{ Country } & \multicolumn{5}{|c|}{ Indices } \\
\cline { 2 - 6 } & $\begin{array}{c}\text { Territory, } \\
\text { thousand } \\
\text { square km. }\end{array}$ & $\begin{array}{c}\text { Population, } \\
\text { in millions }\end{array}$ & $\begin{array}{l}\text { Unemployment } \\
\text { rate, \% }\end{array}$ & $\begin{array}{c}\text { Average } \\
\text { monthly wages, } \\
\text { USD }\end{array}$ & $\begin{array}{c}\text { GDP } \\
\text { in billion } \\
\text { USD }\end{array}$ \\
\hline \multicolumn{1}{c|}{1} & \multicolumn{1}{c|}{2} & 3 & 4 & 5 & \multicolumn{1}{c|}{6} \\
\hline Great Britain & 242.9 & 62.7 & 8.0 & $4,198.6$ & $2,063.3$ \\
\hline Spain & 506.0 & 46.1 & 21.7 & $3,133.2$ & $1,244.5$ \\
\hline Italy & 303.3 & 60.7 & 8.4 & $3,260.6$ & $1,642.7$ \\
\hline Canada & $9,970.6$ & 34.5 & 7.4 & $4,668.0$ & $1,234.6$ \\
\hline Germany & 357.0 & 81.8 & 5.9 & $3,916.9$ & $2,828.0$ \\
\hline Poland & 312.7 & 38.5 & 9.7 & $1,146.8$ & 692.2 \\
\hline Russian Federation & $17,075.4$ & 143.0 & 6.5 & 806.3 & $2,178.6$ \\
\hline Slovenia & 20.2 & 2.1 & 8.2 & $2,557.3$ & 50.3 \\
\hline USA & $9,629.1$ & 312.0 & 8.9 & $4,537.5$ & $13,299.1$ \\
\hline Croatia & 56.5 & 4.3 & 13.5 & $1,459.4$ & 70.3 \\
\hline Montenegro & 13.8 & 0.6 & 19.7 & 658.0 & 6.6 \\
\hline Ukraine & 603.5 & 45.5 & 7.9 & 330.5 & 291.1 \\
\hline
\end{tabular}

Source: (Derzhavna sluzhba statystyky Ukrayiny, 2013)

According to the data in table 1 Ukraine, despite the large area and population, as well as the initial favorable conditions of development after the collapse of the Soviet Union, now has the lowest standards of living in Europe. Correspondingly, the insignificant level of GDP compared to other countries makes Ukraine weak according to the criteria for monetary flows - the volume of intereconomic operations, income, bank resources, etc. Meanwhile, the price levels of food, utilities, transport are lower several times than in Europe.

Thus, when the exchange rate of the UAH to the dollar during 2011-2013 was 8:1, and euro was $11: 1$, and in early 2014 , was respectively $10: 1$ and $14: 1$ the standard of living is satisfactory.

Thus, the cost of utilities in 2014 for an apartment with the area of $60-70 \mathrm{~m}^{2}$ is approximately $40-45$ euro, and public transportation fare is $0.1-0.15$ euro per trip.

According to the Tax Service of Ukraine there were $3011 \mathrm{UAH}$ millionaires in Ukraine and according to the rates of magazine "Forbs" there were 5 "dollar" billionaires.

It should be also noted that official statistics of Ukraine indicated that the economy inflation constitutes $50 \%$. The situation with the indicators, forming the financial flows, leads to uncontrolled and unpredictable processes.

Let us take, for example, Ukraine's GDP. The study will be started with the structure of GDP during 2009-2012 (Table 2) (Derzhavna sluzhba statystyky Ukrayiny, 2013, p. 35).

Table 2 Gross domestic product by the categories of the final use

\begin{tabular}{|l|r|r|r|r|}
\hline \multirow{2}{*}{} & \multicolumn{1}{|c|}{2009} & \multicolumn{1}{|c|}{2010} & \multicolumn{1}{|c|}{2011} & \multicolumn{1}{|c|}{ million UAH } \\
\cline { 2 - 5 } & \multicolumn{4}{|c|}{ UA12 } \\
\hline GDP & 913,345 & $1,082,569$ & $1,302,079$ & $1,408,889$ \\
\hline Final consumer expenditures & 772,826 & 914,230 & $1,113,008$ & $1,269,601$ \\
\hline Households & 581,733 & 686,082 & 865,860 & 986,540 \\
\hline Gross fixed capital formation & 167,644 & 195,927 & 241,785 & 265,349 \\
\hline Goods and services export & 423,564 & 549,365 & 707,953 & 717,347 \\
\hline Goods and services import & 438,860 & 580,944 & 788,901 & 835,394 \\
\hline
\end{tabular}


As it can be seen from table 2 the GDP during 2009-2012 continued to grow. In terms of comparisons to the previous year, the increase took place as follows: 2009 to $2008-85.2 \%, 2010$ to $2009-104.1 \%$, 2011 to $2010-105.2 \% 2012$ and $2011-100.2 \%$ (Derzhavna sluzhba statystyky Ukrayiny, 2013, p. 27). This disparity can be explained by the actions of the State to management to overcome the effects of the financial crisis.

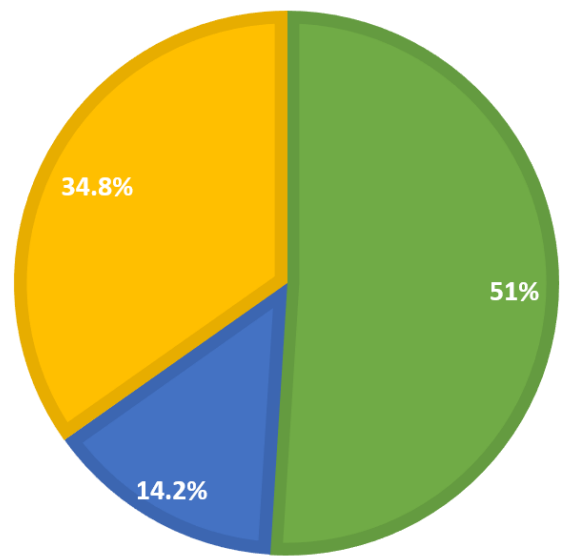

Fig. 2 GDP structure by the income criteria in 2012, \%

Despite the relatively large volumes of GDP in monetary equivalents according to the data of table 1 in dollar terms it is 10 times less. Therefore, Ukraine's GDP compared to such countries as Poland is 2.4 times smaller, Spain - 4.3 times, and in relation to the developed European countries Great Britain - 7.1imes, Italy - 5.6 times, and Germany - 9.7 times.

Ukraine, even after a rather difficult political and economic circumstances in early 2014, has the potential to increase GDP, contributed by the relevant factors of output growth in agriculture, construction, metallurgy, food sectors.
A negative external imbalance which by the way, is continuing to grow every year, had also a significant impact on these processes.

In the structure of GDP for the period of 2012 almost half goes to salaries of employees (Figure 2) (Derzhavna sluzhba statystyky Ukrayiny, 2013, p. 34).
- Salaries of employees

- Taxes, subsides on production, and import are not included - GDP, mixed income

Table 3 Consolidated budget of Ukraine (million UAH)

\begin{tabular}{|c|c|c|c|c|c|}
\hline & 2009 & 2010 & 2011 & 2012 & $\begin{array}{c}2012 \text { to } 2009 \\
\%\end{array}$ \\
\hline Income & $272,967.0$ & $315,406.0$ & $398,554.0$ & $445,525.0$ & 163.2 \\
\hline Tax income & $208,073.2$ & $234,447.7$ & $334,691.9$ & $360,567.2$ & 167.3 \\
\hline Non-tax income & $58,435.8$ & $73,837.0$ & $60,003.7$ & $80,923.3$ & 138.5 \\
\hline Expenditures & $307,399.4$ & $377,842.8$ & $416,853.6$ & $492,454.7$ & 160.2 \\
\hline All-state functions & $33,156.0$ & $44,902.5$ & $49,874.7$ & $54,590.2$ & 164.6 \\
\hline Defense & 9663.3 & $11,347.1$ & $13,242.2$ & $14,486.9$ & 149.9 \\
\hline Economic activities & $39,753.0$ & $43,832.4$ & $57,124.1$ & $62,377.4$ & 156.9 \\
\hline Health care & $36,564.9$ & $44,745.4$ & $48,961.6$ & $58,453.9$ & 160.0 \\
\hline Education & $66,773.6$ & $79,826.0$ & $86,253.6$ & $101,560.9$ & 152.1 \\
\hline $\begin{array}{l}\text { Social protection and } \\
\text { social security }\end{array}$ & $78,775.4$ & $104,534.9$ & $105,434.8$ & $125,306.9$ & 159.0 \\
\hline
\end{tabular}


As it can be seen from table 3 revenues and expenditures of the consolidated budget of Ukraine during 2009-2012 in absolute terms were permanently increasing, and it should be noted that costs increased slightly to a lesser value, although in absolute value, they are great. It can be explained by a permanent budget deficit.

The increasing role of tax revenues in the income structure, grounded by the ordering of the tax revenue due to the adoption of the Tax Code of Ukraine, which entered into force in 2011, should also be noted.

The reduction in defense spending, compared with total expenditure should also be noted as a negative fact.

The budget policy for one year is formed in accordance with the Constitution of Ukraine and the Budget Code of Ukraine. This process involves the Ministry of Finance, Ministry of Economy and Trade, the National Bank of Ukraine. These directions are discussed at the meeting of the Cabinet of Ministers of Ukraine, agreed with the President of Ukraine and submitted for the approval by the Supreme Council of Ukraine.

This document specifies the amount of public debt, its structure, the current weight of intergovernmental transfers and equalization coefficients for local budgets, the share of capital investment expenditures of the State budget.

The starting point for the calculation of budget revenues at all levels, as well as spending is to evaluate the performance of the consolidated and state budget in previous years.

However, despite the elaborate since Ukraine's independence planning system revenues and expenditures, the level of collection of revenues to the budgets of all levels is inadequate. Expenditure planning is also ineffective. It occurs under the following conditions:

- lack of conceptual strategic research on political, social and economic development;

- revenues and expenditures planning practice of the consolidated and state budget for one year, although the Budget Code of Ukraine provides for a three-year term;

- lack of an effective mechanism for planning of expenditures for economic development and social needs;

- ineffective control over the revenues and expenditures of public funds.

To control the financial flows forming the consolidated budget a special attention must be paid to the tax flows. Almost before the beginning of 2014 in Ukraine there was no clear control over the activities of individual business units, allowing them to hide large sums from paying. Certain tax corruption schemes prevented from collecting taxes. To remedy this situation, it is advisable to apply the following principles of management of tax payments:

- necessity to use rules on taxes and fees, determined on the basis of actual data about tax objects and tax liability of taxpayers for tax violations;

- equality which means the prevention of any discrimination, insurance of an objective approach to entities in determining the obligations of taxpayers and charges that carry mandatory payments, the only approach that should provide the best approach to the design and implementation of tax legislation with the definition of a particular taxpayer, the tax object, source tax, identification of the tax period, tax rates, the justification of grounds for granting benefits to individuals and corporate taxpayers, equality and proportionality, which involves tax collecting from legal entities and individuals in a certain proportion of earned income and the corresponding tax provision of proportionality depending on the amounts of income, economic soundness, which implies that the fair tax and duties with regard to indicators of the national economic development, individual regions, which aims to balance the cash flows of the budget income, the uniformity of payment, which includes the timing of the payment of taxes and fees for expenditures to fund programs for economic development, administrative and military structures, law enforcement, various social benefits, including low-income families with children, the disabled, etc.; competence, which includes installation and adjustment of taxes and fees, as well as the benefits to businesses and individual tax payers defined in the Tax Code structures, including the Supreme Council of Ukraine, city, town, village councils, accessibility, providing security, clarity of tax laws for all workers, without exception, the tax service bodies, employees of financial institutions of local state administrations and local self-government, individuals and corporate taxpayers; social justice, which includes providing social support to the poor 
using differentiated and progressive income taxation.

- using a synergistic approach for the formation of the budgetary flows allows to develop effective schemes of budgetary flows;

- taking into account the power of influence of external and internal factors, including those formed by the state management, and in some cases may be of decisive importance;

- identify institutional change in future periods, with the important and significant impact on the final budget figures. The institutional changes include: the dynamics of world markets on major financial markets, exchange rate against other currencies, inflation, the dynamics of energy prices, increases in minimum social standards, GDP growth, taking into account the volume of production in key sectors of the economy of Ukraine.

Budgetary flows are relatively small compared to those the population was involved, therefore let us find out the features of the management of these financial flows.

\section{HOUSEHOLD INCOME}

Let us study the situation with the financial flows forming the household income. The data from table 4 is to be analyzed with this purpose (Derzhavna sluzhba statystyky Ukrayiny, 2013, p. 375).

Table 4 Income and savings of the population (m/n. UAH)

\begin{tabular}{|l|c|r|r|r|c|}
\hline & 2009 & 2010 & \multicolumn{1}{|c|}{2011} & \multicolumn{1}{c|}{2012} & $\begin{array}{c}2012 \text { to } 2009 \\
\%\end{array}$ \\
\hline Income & 894,286 & $1,101,175$ & $1,266,753$ & $1,407,197$ & 157.4 \\
\hline including & & & & & \\
\hline \multicolumn{1}{|c|}{ salaries } & 365,300 & 449,553 & 529,133 & 593,213 & 162.4 \\
\hline \multicolumn{1}{|c|}{ social service } & 364,572 & 423,741 & 469,386 & 526,944 & 144.5 \\
\hline Expenditures & 894,286 & $1,101,175$ & $1,266,753$ & $1,407,197$ & 157.4 \\
\hline Goods and services & 709,025 & 838,213 & $1,030,635$ & $1,179,071$ & 166.3 \\
\hline
\end{tabular}

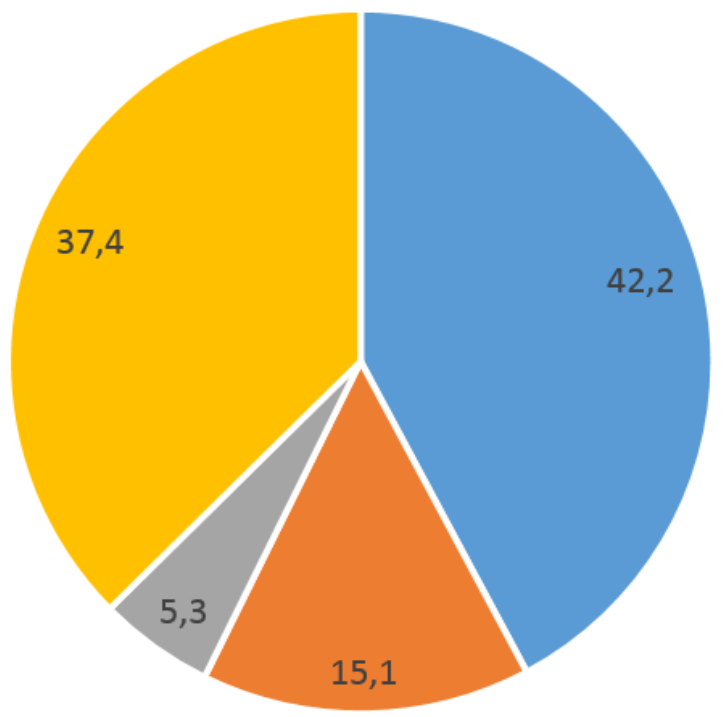

- Wages $42.2 \%$

Fig. 3 Structure of the household income in 2012 in \%

Table 4 shows that household incomes are constantly rising, and are actively involved in the structure of all financial flows of the States.

Taking into account that the situation of the income and purchasing power of the population of Ukraine in comparison with other countries was briefly described above, it can be added that about twenty percent of Ukraine's population is poor, and about thirty percent gets salaries that are lower than average ones in Ukraine.

Let us analyze the household income structure in 2012 (fig. 3) (Derzhavna sluzhba statystyky Ukrayiny, 2013, p. 376). 
As it can be seen from Fig. 3 the largest share in the structure of income is wages $(42.2 \%)$, and various social benefits (37.4\%).

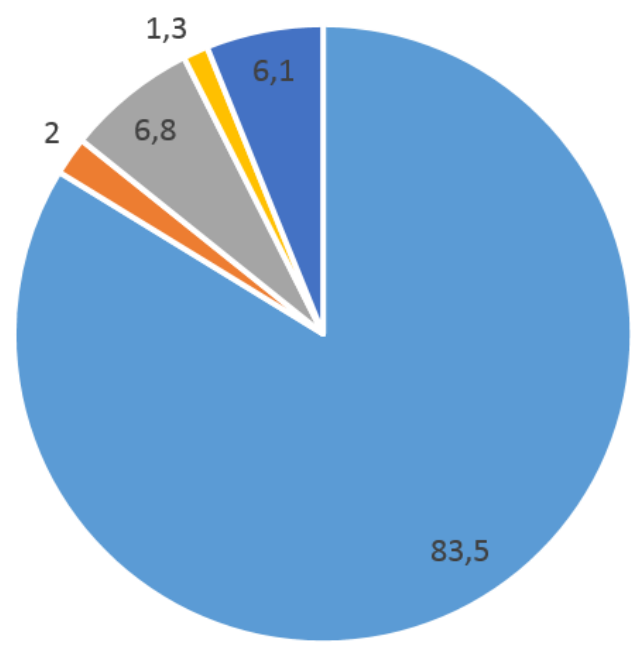

Here are data on household spending (Figure 4) (Derzhavna sluzhba statystyky Ukrayiny, 2013, p. 376).

- Purchase of goods and services $83.5 \%$

- Property income (paid) $2 \%$

- Current taxes on income, property, and other paid current transfers $6.8 \%$

- Build-up of non-financial assests 1.3

- Growth of financial assests $6.1 \%$

Fig. 4 Structure of the spending and savings of the population in 2012, \%

As it can be seen from Fig. 4 people in Ukraine have a rather large share of the costs for the purchase of goods and services $-83.8 \%$, and an extremely small fraction - the actual financial savings $-6.1 \%$.

This situation is justified by the fact that despite the relatively low inflation rate $-12.3 \%$ in 2009 , $9.1 \%$ in $2010,4.6 \%$ in 2011 and $0.2 \%$ (deflation) in 2012 the population does not feel promising stability and therefore invests money in durable goods. The low level of financial savings is due to the sharp "jumps" of the national currency against the dollar and 8,2:1 10.5:1 euro during 2010-2013 and 10.0:1 14,5:1 and in the euro at the beginning of 2014 .

The particularities of the financial flows calculated by the National Bank of Ukraine will be investigated (Table 5) (Derzhavna sluzhba statystyky Ukrayiny, 2013, p. 59).

Table 5 Currency in circulation in Ukraine (at the end of the year, mln. UAH)

\begin{tabular}{|l|c|c|c|c|c|}
\hline & 2009 & 2010 & 2011 & 2012 & $\begin{array}{c}2012 \text { to } 2009 \\
\%\end{array}$ \\
\hline Monetary supply (M0) & 157,029 & 182,990 & 192,665 & 203,245 & 129.4 \\
\hline Monetary supply (M1) & 233,748 & 289,894 & 311,047 & 323,225 & 138.2 \\
\hline Monetary supply (M2) & 484,772 & 596,841 & 681,801 & 771,126 & 159.1 \\
\hline Monetary supply (M3) & 487,298 & 597,872 & 685,515 & 773,199 & 158.7 \\
\hline
\end{tabular}

Monetary aggregates are obligations of depository corporations to other resident sectors such as general government agency and other depository corporations. Money supply MO comprises currency in circulation outside depository corporations. Monetary aggregate M1 - M0 monetary aggregate and transferable deposits in national currency. Monetary aggregate M2 - M1 monetary aggregate and transferable deposits in foreign currency and other deposits. Monetary aggregate M3 - M2 monetary aggregate and securities other than shares. Since 2003, monetary aggregates are based on standardized report forms for the National Bank of Ukraine and other depository corporations (banks) according to the IMF methodology. The data on household savings on deposit are presented (Table 6) (Derzhavna sluzhba statystyky Ukrayiny, 2013, p. 59). 
Table 6 Deposits of households, employed by the deposit corporations (National Bank of Ukraine is not included) (at the end of the year, mln. UAH)

\begin{tabular}{|c|c|c|c|c|c|}
\hline & 2009 & 2010 & 2011 & 2012 & $\begin{array}{c}2012 \text { tol } 2009 \\
\%\end{array}$ \\
\hline Total & 214,098 & 275,093 & 310,390 & 369,264 & 172.5 \\
\hline In currency & & & & & \\
\hline National & 101,081 & 142,924 & 160,530 & 186,772 & 184.8 \\
\hline Foreign & 113,017 & 132,169 & 149,860 & 182,493 & 161.5 \\
\hline
\end{tabular}

The data in table 6 shows that household incomes are growing quite actively, thus as it follows from the data in table 5 the available money supply M3 for the resulting index does not exceed the GDP growth rate for the respective years, which is evidence of a relatively tight monetary policy of the NBU during these periods and the prevention of the unwarranted inflation.

There feasibility of managing these funds is to support innovative development of Ukraine. However, high interest rates to attract credit resources of the banking system - from 25 to $35 \%$ for a year substantially limit these opportunities.

Regarding personal income forming strong monetary flows is the income of "labor immigrants", citizens of Ukraine, who went abroad to work. According to estimates of experts of the National Bank of Ukraine and the Ministry of Finance of Ukraine the number of immigrants reaches 3 million, and monetary flows, legally going through banks, in 2012 reached nearly 10 billion U.S. dollars. The taxation problem of income was revealed by the Tax Service of Ukraine, has found considerable opposition from the general population and has not been implemented.

Regarding the objective necessity of forecasting financial flows it is advisable to use a technique suggested by Ukrainian scientists S. Londar, R. Shevchenko (Londar \& Shevchenko, 2011, pp. 65-66).

When forecasting using the elasticity, the elasticity of the predicted performance based on changes in the tax base is estimated (usually - GDP, GVA, payroll, etc.) in retrospect, and the coefficient of elasticity is based on future periods. On this basis the forecast of economic indicators for the future is done.

The elasticity shows a relative change (percentage) of the economic indicator at the relative change in the independent variable $\mathrm{X}$ for $1 \%$.

Elasticity is calculated by the formula:

$E_{y(x)}=\frac{x}{y} \cdot \frac{\Delta y}{\Delta x}$

Correspondingly:

$\Delta y=\frac{E \cdot y \cdot \Delta x}{x}$

Therefore the predicted value equals to:

$y_{\Pi P}=y+\Delta y=y+\frac{E \cdot y \cdot\left(x_{1}-x\right)}{x}=y\left[1+E\left(\frac{x_{1}}{x}-1\right)\right]$

where $x_{1}$ is a future value of the factor value (Londar \& Shevchenko, 2011, pp. 65-66).

Using this technique allows to calculate the corresponding financial flows in the expected dimension.

\section{CONCLUSIONS}

Management of financial flows in any country takes a crucial importance because it governs the dynamics of economic growth, thus directly affecting the well-being of the population.

The analysis of the management of financial flows in Ukraine during 2009-2012 years in particular in the formation of the consolidated budget, household incomes showed that the effective management of these flows prevented corruption, lack of strategic planning of the economic system as a whole and individual sectors, the lack of proper control of these flows. As a result in terms of living standards Ukraine occupies last position in Europe.

Country renovation that began in 2014 will definitely promote the formation of new social relations, including the economic area, in particular the formation of transparent financial flows. 


\section{WORKS CITED}

Burtsev, V. V. (2001). Osnovnoy konkurentnyy potentsial strany-sistemy v usloviyakh finansovoy transnatsionalizatsii. Finansovyy menedzhment(6), 20-27.

Derzhavna sluzhba statystyky Ukrayiny. (2013). Statystychnyy shchorichnyk Ukrayiny na 2012 r. (O. H. Osaulenko, Ed.) Kiev: TOV "Avhust-Treyd".

Lazicheva, E. A. (2009). Issledovaniye sushchnosti finansovykh potokov. Vestnik Tomskogo gosudarstvennogo universiteta(329), 186-189. Retrieved 07 23, 2014, from Cyberleninka.ru: http://cyberleninka.ru/article/n/issledovanie-suschnosti-finansovyh-potokov

Londar, S. L., \& Shevchenko, R. Y. (2011). Teoretyko-metodolohichni pidkhody do seredn'ostrokovoho prohnozuvannya nadkhodzhen' z podatku na dokhody fizychnykh osib. Naukovi pratsi NDFI, 4(57), 62-69.

Olson, M. (2004). Lohika kolektyvnoyi diyi. Suspil'ni blaha i teoriya hrup / Pereklad z anhl.: The Logic of Collective Action: Public Goods and the Theory of Groups. Kiev: Libra.

Romanovski, M. B. (2009). Finansy. Moskva: Yurayt-Izdat.

Senchagov, V. K., \& Arkhipov, A. I. (2007). Finansy, denezhnoye obrashcheniye i kredit (2 ed.). Moskva: Prospekt.

Tikhomirov, Y. F. (2008). Finansovyy menedzhment: upravleniye finansami predpriyatiya. Moskva: Akademiya.

Received for publication: $\quad 31.03 .2014$

Revision received: $\quad 24.04 .2014$

Accepted for publication: $\quad 24.07 .2014$

\section{How to cite this article?}

Style - APA Sixth Edition:

Pasichnyk, I. V. (2015, Jan 15). Financial management of monetary flows in Ukraine. (Z. Čekerevac, Ed.) MEST Journal, 3(1), 1-10. doi:10.12709/mest.03.03.01.01

Style - Chicago Fifteenth Edition:

Pasichnyk, lurii Vasyliovych. 2015. "Financial management of monetary flows in Ukraine." Edited by Zoran Čekerevac. MEST Journal (MESTE) 3 (1): 1-10. doi:10.12709/mest.03.03.01.01.

Style - GOST Name Sort:

Pasichnyk lurii Vasyliovych Financial management of monetary flows in Ukraine [Journal] // MEST Journal / ed. Čekerevac Zoran. - Belgrade : MESTE, Jan 15, 2015. - 1 : Vol. 3. - pp. 1-10.

Style - Harvard Anglia:

Pasichnyk, I. V., 2015. Financial management of monetary flows in Ukraine. MEST Journal, 15 Jan, 3(1), pp. 1-10.

Style - ISO 690 Numerical Reference:

Financial management of monetary flows in Ukraine. Pasichnyk, lurii Vasyliovych. [ed.] Zoran Čekerevac. 1, Belgrade : MESTE, Jan 15, 2015, MEST Journal, Vol. 3, pp. 1-10. 